\title{
Assessment of anaemia in adolescent girls
}

\author{
Jayant V. Upadhye ${ }^{1}$, Jayshree J. Upadhye ${ }^{2 *}$
}

\begin{abstract}
${ }^{1}$ Department of Paediatric and Neonatology, ${ }^{2}$ Department of Gynecology and Obstetrics, Upadhye Children hospital,
\end{abstract} Nagpur, Maharashtra, India

Received: 14 May 2017

Accepted: 10 June 2017

\section{*Correspondence:}

Dr. Jayshree J. Upadhye,

E-mail: jayshreeupadhye@gmail.com

Copyright: ( ) the author(s), publisher and licensee Medip Academy. This is an open-access article distributed under the terms of the Creative Commons Attribution Non-Commercial License, which permits unrestricted non-commercial use, distribution, and reproduction in any medium, provided the original work is properly cited.

\section{ABSTRACT}

Background: The world's adolescent population is facing a series of serious nutritional challenges which are not only affecting their growth and development but also their livelihood as adults. Yet, adolescents remain a largely neglected, difficult to measure and hard to reach population, in which the needs of adolescent girls in particular, are often ignored. Anemia in adolescent girls contributes to maternal and foetal mortality and morbidity in future. The objective of the study was to estimate the frequency of anemia among adolescent girls, to study the sociodemographic factors associated with anemia and to evaluate the cause and type of anaemia.

Methods: A cross-sectional survey was conducted in an urban area in a school. A total of 300 girls (12-18 years) were included in this study. Statistical analysis was done using percentage, standard error of proportion, Chi-square test and student's t-test.

Results: The prevalence of anemia was found to be $90 \%$. A significant association of anemia was found with socioeconomic status and literacy status of parents. Mean height and weight of subjects with anemia was significantly less than subjects without anemia. A high prevalence of anemia among adolescent females was found, among those whose parents were less educated.

Conclusions: The overall prevalence of anemia among adolescent females was found to be $90 \%$. There is significant association of anemia with socio-economic status and parents' educational status. There is need to increase awareness of anemia in adolescent girls and parents.

Keywords: Adolescence, Anaemia, Maternal and foetal mortality

\section{INTRODUCTION}

Adolescence has been defined by the World Health Organization as the period of life spanning the ages between 10 to19 years. ${ }^{1}$ This is the formative period of life when the maximum amount of physical, psychological, and behavioral changes take place. This is a vulnerable period in the human life cycle for the development of nutritional anemia. ${ }^{2}$

Anemia has a negative effect on cognitive performance in adolescents. ${ }^{3}$ Compared to the vast amount of work done in pregnant mothers and young children, there are relatively few published studies in India evaluating deficiencies of Iron, Vitamin B12 and Folate in adolescents having nutritional anemia and its association with severity of anemia. ${ }^{3}$

In response to the problem, the national Ministry of Health and Family Welfare (MHFW) launched a nationwide Weekly Iron and Folic Acid Supplementation (WIFS) programme in January 2013-14 UNICEF India has been the partner of choice in supporting the universal roll-out of the programme in 14 major states in India. ${ }^{4}$ 
The pre-pregnancy nutritional status of young girls is important as it impacts on the course and the outcome of their pregnancy. Hence, the health of adolescent girls demands special attention. ${ }^{5}$

Adolescent girls are at a high risk for anaemia and malnutrition. Inadequate nutrition during adolescence can have serious consequences throughout the reproductive years of life and beyond. Very often, in India, girls get married and pregnant even before the growth period is over, thus doubling the risk for anaemia. ${ }^{5}$ During this period, iron requirements increase dramatically as a result of the expansion of the total blood volume, the increase in lean body mass and the onset of menses in young females. ${ }^{6}$ The overall iron requirements increase from a preadolescent level of $\sim 0.7-0.9 \mathrm{mg} \mathrm{Fe} / \mathrm{d}$ to as much as $2.2 \mathrm{mg} \mathrm{Fe} / \mathrm{d}$ or perhaps more in heavily menstruating young women. These increased requirements are associated with the timing and size of the growth spurt as well as sexual maturation and the onset of menses.6 Regular nutritional education sessions should be carried out to increase awareness in adolescent girls regarding anemia. $^{7}$

This study was conducted to highlight the problem of anemia in adolescent girls and to study sociodemographic factors related to anemia.

\section{METHODS}

300 girls between 12-16 years of age were screened for anaemia by Sahli's haemoglobinometer. Girls were screened at Tip Top convent school, Nagpur. Tip Top Convent is a school situated in urban area of Nagpur. This was cross sectional study conducted in this school.

A survey was carried out by the investigators. After obtaining written informed consent from the Principal, information about the socio-demographic characteristics, education of parents was recorded in the proforma. This was followed by a clinical examination of the girls including height and weight. Socio-economic status (SES) was estimated according to a modified Kuppuswamy's scale. The total number of members in the family constituted the family size. For hemoglobin estimation, Sahli's hemoglobinometer was used. Hemoglobin estimation was done by Sahli's method using acid haematin method. Patients were classified into mild, moderate and severe anaemia. Patients with moderate and severe anaemia were further investigated to find the cause and type of anaemia.

Criteria for anemia is $\mathrm{Hb}<12 \mathrm{gm} \%$

The severity of anemia was graded as

- $\quad$ Mild 10-11.9 g/dL

- Moderate 7-9.9 g/dL

- $\quad$ Severe $<7 \mathrm{gm} / \mathrm{dl}$

\section{Statistical analysis}

The statistical analysis was done using Chi-square test, Students $\mathrm{t}$ test, mean, standard error of proportion, etc. The help of a statistician was sought while analyzing the data.

\section{RESULTS}

Out of 300 girls, 270 girls were found to be anaemic. Thus, prevalence of anaemia was very high i.e. $90 \%$ in our study.

Table 1: Prevalence of anemia.

\begin{tabular}{|lll|}
\hline $\begin{array}{l}\text { Haemoglobin } \\
(\%)\end{array}$ & No. of girls & Percentage (\%) \\
\hline$<12$ gm & 270 & 90 \\
\hline$>12$ gm & 30 & 10 \\
\hline
\end{tabular}

Modified Kuppuswamy scale was used to assess the socioeconomic status of the family. A statistically significant association of anemia was found with the socio-economic status.

$50 \%$ girls were from lower middle (III) class, $33.3 \%$ girls were from upper lower (IV) class while $16.6 \%$ girls were from upper middle (II) class. None of the subjects belonged to socio-economic strata I (upper) and V (lower). There was significant association of anaemia with socio-economic status.

Table 2: Socio-economic status.

\begin{tabular}{|lll|}
\hline $\begin{array}{l}\text { Socioeconomic } \\
\text { status }\end{array}$ & No. of girls & Anaemic girls \\
\hline Upper (I) & 0 & 0 \\
\hline Upper middle (II) & $50(16.6 \%)$ & $35(70 \%)$ \\
\hline Lower middle (III) & $150(50 \%)$ & $140(93.3 \%)$ \\
\hline Upper lower (IV) & $100(33.3 \%)$ & $95(95 \%)$ \\
\hline Lower (V) & 0 & 0 \\
\hline
\end{tabular}

Chi sq. $=26.85 \mathrm{p}=0.0000014$ significant

A statistically highly significant association of anemia was found with the mother 's and father's educational status.

$56.67 \%$ mothers had primary education where anemia was seen in $95.88 \%$ girls. $26.67 \%$ mothers had education till middle school where anemia was seen in $91.25 \%$ girls. $10 \%$ mothers had education till 10th standard or more where anemia was seen in $53.33 \%$ girls.6.67\% mothers were illiterate where anemia was seen in $90 \%$ girls. $46.67 \%$ fathers had education till middle school where $98.57 \%$ girls were anaemic, $33.3 \%$ fathers had education till 10th standard or more where $75 \%$ girls were anaemic, $16.67 \%$ fathers had education till primary school where $96 \%$ girls were anaemic, $3.33 \%$ fathers were illiterate where $90 \%$ girls were anaemic. 
Table 3: Co-relation of parent's education with anaemia.

\begin{tabular}{|c|c|c|c|c|}
\hline Parent's education & No. of girls & No. of anaemic girls & Chi sq. & P value \\
\hline Mother's education & & & & \\
\hline Illiterate & $20(6.67 \%)$ & $18(90 \%)$ & \multirow{4}{*}{51.49} & \multirow{4}{*}{$<0.001$ significant } \\
\hline Primary & $170(56.67 \%$ & $163(95.88 \%)$ & & \\
\hline Middle & $80(26.67 \%)$ & $73(91.25 \%)$ & & \\
\hline SSC or higher & $30(10 \%)$ & $16(53.33 \%)$ & & \\
\hline \multicolumn{5}{|l|}{ Father's education } \\
\hline Illiterate & $10(3.33 \%)$ & $9(90 \%)$ & \multirow{4}{*}{38.43} & \multirow{4}{*}{$<0.001$ significan } \\
\hline Primary & $50(16.67 \%)$ & $48(96 \%)$ & & \\
\hline Middle & $140(46.67 \%)$ & $138(98.57 \%)$ & & \\
\hline SSC or higher & $100(33.33 \%)$ & $75(75 \%)$ & & \\
\hline
\end{tabular}

Out of 270 girls, 220 girls $(73.3 \%)$ had mild anemia (Hb 10 to $<12 \mathrm{gm} \%)$ while 50 girls $(16.6 \%)$ had moderate anemia ( $\mathrm{Hb} 7$ to $<10 \mathrm{gm} \%)$. None of the subjects had severe anemia. So, majority of the girls were mildly anaemic.

Table 4: Severity of anemia.

\begin{tabular}{|lll|}
\hline Type of anaemia & No. of girls & $\%$ of anaemia \\
\hline No anaemia & 30 & 10 \\
\hline Mild anaemia & 220 & 73.3 \\
\hline Moderate anaemia & 50 & 16.6 \\
\hline Severe anaemia & 00 & 0 \\
\hline
\end{tabular}

It was found that mean height and mean weight of subjects with anemia is less as compared with that of subjects without anemia; the difference was statistically significant.

Table 5: Comparison of mean height and mean weight of subjects with and without anemia.

\begin{tabular}{|lllll|}
\hline Variable & $\begin{array}{l}\text { Girls } \\
\text { with } \\
\text { anaemia } \\
(270)\end{array}$ & $\begin{array}{l}\text { Girls } \\
\text { without } \\
\text { anaemia } \\
(30)\end{array}$ & $\begin{array}{l}\text { t- } \\
\text { value }\end{array}$ & $\begin{array}{l}\text { p- } \\
\text { value }\end{array}$ \\
\hline $\begin{array}{l}\text { Mean } \\
\text { height }(\mathrm{cm})\end{array}$ & $\begin{array}{l}148.94 \\
(10.74)\end{array}$ & $\begin{array}{l}153.27 \\
(9.62)\end{array}$ & -1.96 & 0.05 \\
\hline $\begin{array}{l}\text { Mean } \\
\text { weight }(\mathrm{kg})\end{array}$ & $\begin{array}{l}37.43 \\
(10.45)\end{array}$ & $\begin{array}{l}40.62 \\
(10.43)\end{array}$ & -1.35 & 0.179 \\
\hline
\end{tabular}

Girls with mild anaemia were given $1 \mathrm{tab}$ of $200 \mathrm{mg}$ of ferrous sulfate containing $60 \mathrm{mg}$ of elemental iron and 1 tablet of folic acid $5 \mathrm{mg}$ daily. Girls with moderate anaemia were further investigated with complete blood count by automated cell counter, peripheral smear for opinion and hemoglobin electrophoresis. It was found that $56 \%$ girls had iron deficiency anemia while $36 \%$ girls had dimorphic anemia, $6 \%$ had sickle cell trait while $2 \%$ had thalassemia. Hemoglobin electrophoresis of 46 patients was normal. These girls were given 1 tablet of $200 \mathrm{mg}$ of ferrous sulfate containing $60 \mathrm{mg}$ of elemental iron and 1 tablet of folic acid $5 \mathrm{mg}$ daily. Patients with sickle cell trait and thalassemia minor were given folic acid tablet $5 \mathrm{mg}$ daily.

Table 6: Peripheral smear examination.

\begin{tabular}{|lll|}
\hline Peripheral smear & No. of girls & $\%$ \\
\hline Iron deficiency anaemia & 28 & 56 \\
\hline Dimorphic anaemia & 18 & 36 \\
\hline Sickle cell trait & 3 & 6 \\
\hline Thalassemia minor & 1 & 2 \\
\hline
\end{tabular}

\section{DISCUSSION}

Anaemia is a long-standing problem in India with high prevalence of anaemia in adolescents. India has the world's highest prevalence of iron deficiency anaemia among women, and $70 \%$ of the adolescent girls being anaemic.

\section{Prevalence of anaemia}

In present study, 300 girls between 12-16 years of age were screened for anaemia. The overall prevalence of anemia was found to be $90 \%$ in the present study. Sanjeev Chaudhary and Vasant Dhage reported 35.1\% prevalence in urban area of Nagpur, Maharashtra. ${ }^{2}$ Biradkar $\mathrm{S}$ et al, found that the overall prevalence of anaemia was $41.1 \% .^{5}$ Kulkarni $\mathrm{M}$ et al, found that out of 272 adolescent girls in the study population, $245(90.1 \%)$ girls were found to be anemic. ${ }^{7} 35.1 \%$ prevalence is seen by CMS Rawat et al. ${ }^{8}$

$90.1 \%$ prevalence is found by Rajaratnam $\mathrm{J}$ et al in Tamil Nadu. ${ }^{9}$ Tuteja GS et al, found $90.1 \%$ prevalence of anemia among adolescent girls from 16 districts of India. ${ }^{10}$ Kotecha PV reported $75 \%$ prevalence of anaemia. ${ }^{11}$ Anshu Sharma et al found that $61.9 \%$ of the subjects in the urban and $85.4 \%$ in the rural area were anemia. $^{12}$ Akramipour $\mathrm{R}$ et al, found that the prevalence of anemia $(\mathrm{Hb}<12 \mathrm{mg} / \mathrm{dl})$ among adolescent school girls was $21.4 \% .^{13}$ Creed-Kanashiro HM et al found that the prevalence is $35 \%$ in nonpregnant women of fertile age 
and $24.7 \%$ in adolescent girls in slums of periurban Lima. ${ }^{14}$

\section{Demographic factors}

In the present study, a significant association of anemia was found with socio-economic status. A significant association of the prevalence of anemia with educational status of parents reflects better awareness among literate mothers, as well as better socio-economic conditions. None of the subjects had severe anemia. Biradkar S et al, found that out of the 840 adolescent girls, a majority $(84.2 \%)$ belonged to the socio-economic class IV, whereas $11.5 \%$ of them belonged to class III and only $4.3 \%$ belonged to class $\mathrm{V}$. None of the girls belonged to classes I and II. ${ }^{5}$ The prevalence of anaemia among the girls who belonged to class III was $4.1 \%$, whereas it was $43.1 \%$ in girls of class IV and $100 \%$ in girls of class V. ${ }^{5}$ Kulkarni $\mathrm{M}$ et al found that most of the girls i.e. 228 $(90.48 \%)$ belonged to the socioeconomic class III, IV, V (lower middle, upper lower and lower). ${ }^{7}$

Kulkarni $M$ et al found that adolescent girls with mother's occupation as service or business were less prevalent for anemia as compared to the girls with mothers as housewives or laborers. ${ }^{7}$ In the present study, mean height and mean weight of subjects with anemia was significantly less than subjects without anemia, which suggests that anemia affects the overall growth of adolescents.

\section{Grading of anaemia}

In present study, out of 270 girls, 220 girls (73.3\%) had mild anemia (Hb 10 to $<12 \mathrm{gm} \%$ ) while 50 girls (16.6\%) had moderate anemia ( $\mathrm{Hb} 7$ to $<10 \mathrm{gm} \%$ ). None of the subjects had severe anemia. So, majority of the girls were mildly anaemic. Bulliyy et al found $96.5 \%$ prevalence among non-school going adolescent girls in three districts of Orissa, of which, $45.2 \%, 46.9 \%$, and $4.4 \%$ had mild, moderate, and severe anemia. ${ }^{15}$ They found significant association between hemoglobin concentration and the educational level of girls, their parents' family income, and body mass index. ${ }^{15}$ Deena Thomas et al found that $50.5 \%$ adolescents had mild anemia, $29 \%$ had moderate anemia while $20.5 \%$ had severe anemia. ${ }^{3}$

According to NFHS-3 more than 39\% adolescent girls (15-19 years) are mildly anaemic while $15 \%$ and $2 \%$ suffer from moderate and severe anaemia respectively. ${ }^{16}$ Biradkar SS et al found that out of the 840 adolescent girls, 290 (34.6\%) were mildly anaemic, 53 (6.3\%) were moderately anaemic and $2(0.2 \%)$ were severely anaemic. ${ }^{5}$ Biradkar $\mathrm{S}$ et al, found that the prevalence of severe anaemia was $0.2 \%$, that of moderate anaemia was $6.3 \%$ and that of mild anaemia was $33 \% .{ }^{5}$ Kulkarni M et al, found that majority of the girls $(88.6 \%)$ were having mild to moderate anemia and only $1.5 \%$ girl were severely anemic. ${ }^{7}$

\section{Typing of anaemia}

The majority of subjects with anemia in the present study, $56 \%$ had a microcytic hypochromic picture in the peripheral smear suggestive of iron deficiency anemia, while $36 \%$ subjects had a dimorphic picture. 6\% had sickle cell trait and $2 \%$ had thalassemia minor. Deena Thomas et al found that $55 \%$ had normocytic anemia, $27.5 \%$ had microcytic, $8.5 \%$ had macrocytic, and $9 \%$ had dimorphic anemia. ${ }^{3}$ Khanduri et al, found peak incidences of megaloblastic anemia in the age group of 10-30-yearold $(48 \%)$ with female preponderance $(71 \%)$ in India. ${ }^{17}$

\section{CONCLUSION}

From our study, it is concluded that the overall prevalence of anemia among adolescent females was found to be $90 \%$. It is seen that anemia affects the overall nutritional status of adolescent females. There is significant association of anemia with socio-economic status and parents' educational status. It was found that mean height and mean weight of subjects with anemia is less as compared with that of subjects without anemia; the difference was statistically significant. It was found that out of 270 girls, 220 girls $(73.3 \%)$ had mild anemia (Hb 10 to $<12 \mathrm{gm} \%$ ) while 50 girls (16.6\%) had moderate anemia ( $\mathrm{Hb} 7$ to $<10 \mathrm{gm} \%$ ). None of the subjects had severe anemia. So, majority of the girls were mildly anaemic. Majority (30) girls had iron deficiency anemia while 20 girls had dimorphic anemia.

\section{Recommendations}

The overall prevalence of anemia among adolescent suggests a need

- To develop strategies for intensive adult education.

- To improve the socio-economic status of the population through poverty alleviation programmes.

- This should be supported by programmes for the prevention of anemia among adolescent girls through nutrition education and anemia prophylaxis.

- Prevention of worm infestation.

- $\quad$ Screening of target groups for anaemia.

- Referring anaemic girls to appropriate health facility.

Funding: No funding sources Conflict of interest: None declared

Ethical approval: The study was approved by the Institutional Ethics Committee

\section{REFERENCES}

1. World Health Organization. Programming for adolescent health and development. WHO Tech Rep Ser No. 1996:2. 
2. Chaudhary S, Dhage V. A study of anaemia among adolescent females in urban area of Nagpur, Indian J comm med. 2008;33(4):243-5.

3. Thomas D, Chandra J, Sharma S, Jain A, Pemde HK. Determinants of nutritional anemia in adolescents. Indian pediatrics. 2015;52(10):867-9.

4. Adolescent nutrition, Unicef India. 2013.. Available at http://unicef.in/Whatwedo/33/AdolescentsNutrition.

5. Biradkar S, Biradkar S. Prevalence of Anaemia among Adolescent Girls: A One Year CrossSectional Study, J Clinic Diagnost Res. 2012 (Suppl1);6(3):372-7.

6. Beard JL. Iron requirements in adolescent females. The J nutri. 2000;130(2):440S-2S.

7. Kulkarni MV, Durge PM, Kasturwar NB. Prevalence of anemia among adolescent girls in an urban slum. National J Comm Med. 2012;3(1):108-11.

8. Rawat CMS, Garg SK, Singh JV, Bhatnagar M, Chopra H, Bajai SK. Sociodemographic correlates of anemia among adolescent girls in rural district of Meerut. Indian J Community Med. 2001;26:173-5.

9. Rajaratnam J, Abel R, Asokan JS, Jonathan P. Prevalence of anemia among adolescent girls of rural Tamil Nadu. Indian Pediatr. 2000;37:532-6.

10. Tuteja GS, Singh P, Dhillon BS, Saxena BN, Ahmed FU, Singh RP, et al. Prevalence of anaemia among pregnant women and adolescent girls in 16 districts of India. Food Nutrition Bulletin. 2006;27:311-5.

11. Kotecha PV, Nirupam S, Karkar PD. Adolescent girls' anaemia control programme, Gujarat, India. Indian J Med Res. 2009; 130(5):584-9.
12. Sharma A, Prasad K, Rao KV. Identification of an appropriate strategy to control anemia in adolescent girls of poor communities. Indian Pediatrics. 2000;37(3):261-7.

13. Akramipour R, Rezaei M, Rahimi Z. Prevalence of iron deficiency anemia among adolescent schoolgirls from Kermanshah, Western Iran. Hematol. 2008;13(6):352-5.

14. Creed-Kanashiro HM, Uribe TG, Bartolini RM, Fukumoto MN, López TT, Zavaleta NM, et al. Improving dietary intake to prevent anemia in adolescent girls through community kitchens in a periurban population of Lima, Peru. The Journal of nutrition. 2000;130(2):459S-61S.

15. Bulliyy G, Mallick G, Sethy GS, Kar SK. Haemoglobin status of non-school going adolescent girls in three districts of Orissa, India. Int J Adolesc Med Health. 2007;19:395-406.

16. Press Information Bureau, Government of India, Ministry of Health and Family Welfare. Adolescent Anaemia. 2013;13:18 IST.

17. Khanduri U, Sharma A. Megaloblasticanaemia: Prevalence and causative factors. Natl Med J India. 2007;20:172-5.

Cite this article as: Upadhye $\mathrm{JV}$, Upadhye $\mathrm{JJ}$. Assessment of anaemia in adolescent girls. Int $\mathbf{J}$ Reprod Contracept Obstet Gynecol 2017;6:3113-7. 